We are grateful to Dr. L. I. Woolf for gifts of the aromatic acids used.

Dept. of Pathology,

Guy's Hospital Medical School, London, S.E.1.

Dept. of Chemical Pathology,

Royal Free Hospital, London, W.C.l.

1 Pare, C. M. B., Sandler, M., and Stacey, R. S., Lancet, i, 551 (1957). Feliman, J. H., Proc. Soc. Exp. Biol., N.Y., 93, 413 (1956).

- Clark, C. T., Weissbach, H., and Udenfriend, S., J. Biol. Chem., 210. 139 (1954)

- Gaddum, J. H., and Giarman, N. J., Brit. J. Pharmacol., 11, 88 (1956).

Sherwin, C. P., Wolf, M., and Wolf, W., J. Biol. Chem., 87, 113 (1919).

- Bickis, I. J., Kennedy, J. P., and Quastel, J. H., Nature, 179, 1124 (1957).

\section{Role of Ferrous Iron in Enzymatic Transamination}

Aumhodgh the part played by metals in nonenzymatic transaminations is known, its role in the enzymatic reaction of this type is still to be proved. Aluminium, nickel, copper and iron are known to catalyse the non-enzymatic reaction between an amino-acid and pyridoxal, or a keto-acid and pyridoxamine. Recently, Fasella et al. ${ }^{1}$ have isolated the intermediates involved. This preliminary communication reports the possibility of iron (in its reduced state) being involved in the enzymatic transamination.

The source of the enzyme was the fresh green beans of Dolichos lablab. From the residue after acetone extraction of the beans, aspartic-glutamic transaminase was purified by 'Dowex-2' (in chloride form), calcium phosphate gel and alumina $C \gamma$ treatment. Electrophoresis (on paper) showed that the enzyme moved as a single component $(p H \mathbf{H} \cdot 0$, glycino-sodium hydroxide buffer, $4 \mathrm{~cm}$. in $4 \mathrm{hr}$., $440 \mathrm{~V} ., 26^{\circ} \mathrm{C}$.) indicating a high state of purity. This purified preperation was used in the present work.

Preliminary experiments showed that metals such as aluminium, nickel, copper, magnesium, manganese and cobalt had no appreciable effect on the activity of the enzyme. Ferrous sulphate produced an increase in its activity, whereas mercury (as mercurous chloride) completely inhibited it.

As shown in Table 1, dialysis against 8-oxyquinoline solution $(0.005 M)$ for $17 \mathrm{hr}$. in the cold reduced the activity of the enzyme considerably, but it was

Table 1. Frtect of Frrrous Iron on Aspartic-Glutamio TransAMINASE

Reaction carried out at $37^{\circ} \mathrm{C}$. for half an hour under nitrogen. Activity estimated by the method of Tonhazy (ref. 3 )

\begin{tabular}{|c|c|}
\hline Additions & $\begin{array}{c}\text { Pyruvate } \\
\text { formed } \\
(\mu \mathrm{gm} .) \text { per } \\
\text { mgm. } \\
\text { protein }\end{array}$ \\
\hline 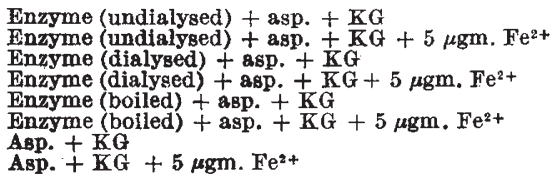 & $\begin{array}{r}1,120 \\
1,160 \\
400 \\
1,230 \\
\text { Nil } \\
\text { Nil } \\
\text { Nil } \\
\text { Nil }\end{array}$ \\
\hline
\end{tabular}

as]. = DL-aspartic acid. $\quad K G=a$-ketoglutaric acid. completely restored by addition of about $5 \mu \mathrm{gm}$. of ferrous iron (as $\mathrm{FeSO}_{4} .7 \mathrm{H}_{2} \mathrm{O}$ ) to the reaction mixture. Also there was no non-enzymatic transamination either in the presence or the absence of ferrous iron. Ferric iron (as $\left.\mathrm{Fe}_{2}\left(\mathrm{SO}_{4}\right)_{3}\right)$ was not active. Addition of ferrous iron to the undialysed enzyme had no effect. Among the various iron binders studied it was noticed that addition of glutathione, versene (disodium salt), $O$-phenanthroline and $\alpha$ - $\alpha$-dipyridyl inhibited the activity by 10-20 per cent. Cyanide completely destroyed the activity, whereas 8-oxyquinoline had no effect at all.

Thus there appeers to be an indication, for the first time, that a metal is involved in enzymatic transamination. In this connexion it can be stated that Dr. Cohen reported the presence of a strong $\mathrm{Fe}$ band in one of the Merck preparations of pyridoxal phosphate which was found to be twice as active as pyridoxal phosphate from other sources ${ }^{2}$. No exogenous coenzyme was used in the present investigation. Further work is in progress to isolate the enzyme in a high state of purity, in order to find whether there is iron in the enzyme, and also its mode of action.

I wish to thank Dr. M. Srinivasan and Mr. Nagabhushanam for their helpful discussions, and Dr. V. Subrahmanyan, director of this Institute, for his interest in the present investigation. Thanks are also due to Glyco Products Inc., New York, for a gift of versene.

\section{V. PatwardhaN}

Division of Biochemistry and Nutrition,

Central Food Technological

Research Institute, Mysore, India.

1 Fasella, P. Lis, H. Biliprandi, N., and Baglioni, C., Biochim. Biophys. Acta, 23, 417 (1957).

2 "Amino-acid Metabolism", Symposium, McCollum-Pratt Institute p. 56 (1955)

${ }^{3}$ Tonhazy, N. E., White, N. G., and Umbreit, W. W., Arch. Biochem. $28,36(1950)$.

\section{Effect of Testosterone and Orchidectomy on the Activity of the Melanocytes in the Skin}

Ir is well known that there is an increased pigmentation of the skin in certain areas of the body in pregnancy. It has also been established that the occurrence of a malignant change in benign pigmented tumours or moles is rare before puberty in both sexes. Furthermore it is accepted that the growth of malignant melanomas and the formation of metastases is accelerated during pregnancy ${ }^{1}$. All these facts suggest that the activity of the melanocyte is under hormonal influence. Edwards, Hamilton, Duntley and Huberta reported that the human male castrate has a reduced amount of melanin in the skin. Treatment of these men with testosterone usually increased the melanin content in all areas, although the response was of small degree. Kupperman ${ }^{3}$, working on the male golden hamster, showed that testosterone increases the pigmentation of the skin, whereas castration causes a reduction in pigmentation. Wheeler et al. ${ }^{*}$ found by macroscopical and microscopical observations that topical application of testosterone to the nipples and areolæ of immature castrated male guines pigs produced no increased pig. mentation. The present investigation was designed to 